\title{
SHATTERED IMAGES: UNDERSTANDING EXPECTATIONS AND REALITIES OF FIELD EXPERIENCES
}

\author{
ARDRA L. COLE \\ The Ontario Institute for Studies in Education, Canada \\ and \\ J. GARY KNOWLES \\ The University of Michigan, U.S.A.
}

\begin{abstract}
In this paper we explore the phenomenon of "shattered images" in the learning to teach process. For our presentation and discussion we draw on: reflective accounts of preservice teachers written prior to, during, and following periods of field experience; our experiences as teachers and teacher educators; and, on our own and other research on teacher education and development, particularly on our ongoing work which focuses on field experiences. We highlight and examine some of the discrepancies between preservice teachers' expectations and experiences, identify and discuss circumstances contributing to the discrepancies, and consider ways in which such inconsistencies might be taken into account in order to develop and maintain productive preservice teacher preparation programs.
\end{abstract}

Back in September when most of us were still starryeyed with excitement, we all dreamed of changing the lives of hundreds of youngsters through our teaching techniques. We knew that if we only tried enough, we could make everyone learn everything they were supposed to learn in the time allotted for them to learn it in, and make all the children love us at the same time. We knew that we were going to stand in front of classrooms and silence the masses with our brilliant and creative ideas for learning how to count to ten, and that the cooperating teachers were going to break our arms patting us on the back, and the principals were going to offer us jobs the day after we graduated because there had never been a teacher like us before. (Patricia Long) ${ }^{1}$

Although this is a slightly overstated representation of how preservice teachers envisage their introduction to life as teachers, there is a fairly strong element of truth in these words. With a tone of disillusionment, it is a retrospective image informed by the wisdom of this person's experience in the field as a preservice teacher. As we read, we wait for the "BUT"-a picture of what it was really like. Going into their field experiences of various kinds, most preservice teachers have hopes, images, and expectations that all too often are quickly shattered by exposure to certain realities of schools, classrooms, and teaching. Dilemmas and difficulties often arise, sometimes leading to failure, when preservice teachers' preconceived ideals or internalized images of teachers, teaching, and schools do not match what they actually encounter. Less extreme repercussions serve to dampen enthusiasm or wipe the sheen from the glass.

\section{Our Perspectives on Teacher Education and Development}

Reflected in our paper is a view of teacher education as a lifelong process of continuing growth with preservice programs, including practica, providing the contexts for the formal beginnings of career-long development. Also

\footnotetext{
${ }^{1}$ Most names used are pseudonyms. Some preservice teachers, however, wished to be identified by their own names.
} 
underpinning our work is the belief that people who enter formal teacher education institutions bring with them many perspectives that represent long-held beliefs about teachers' roles and practices, and about classrooms and schools. And these preconceptions, along with more recent ones developed in the preservice preparation period, converge in the creation of images and expectations of practice which strongly influence preservice teachers' actual experiences of and in classrooms and schools. Finally, giving value to the primacy of experience, we maintain that preservice field experiences are potentially invaluable educative opportunities which too often and unnecessarily are perceived by preservice teachers as mis- or non-educative. We assume, however, that with appropriate attention to individuals, contexts, and programs the potential of field experiences to facilitate more effectively teacher development can be realized.

\section{Methodology, Information Sources, and Interpretive Framework}

A variety of sources inform this paper. Primarily we draw on information gathered in several research projects which are part of an ongoing program of qualitative research on learning to teach. In a Master's degree, secondary school certification, internship program preservice teachers' experiences were recorded through interactive journal accounts and interviews. In an undergraduate degree, elementary school certification program preservice teachers recorded their experiences in interactive journal accounts, reflective papers (ungraded assignments which focused on issues of professional development), autobiographical statements, and solicited written statements (which focused on issues such as relationships with cooperating teachers). In a post baccalaureate degree, elementary and secondary school certification program preservice teachers recorded their experiences in solicited written statements about learning from field experiences. From a variety of contexts, including instructional and research programs, the experiences of preservice teachers who failed student teaching were recorded in journals, interviews, and autobiographical statements.

In our ongoing analysis of these data several themes emerged. The perceived discrepancy between preservice teachers' expectations and experiences of learning to teach is one that repeatedly surfaced, thereby inciting our interest. In this paper we revisit some reflective accounts, recorded by preservice teachers at various times over a span of 5 years, to explore further the apparently pervasive phenomenon of shattered images. We locate our analysis within the theoretical context of the literature on preservice teacher education, particularly on field experiences (e.g., Feiman-Nemser \& Buchmann, 1987; Guyton \& McIntyre, 1990; Lanier \& Little, 1986; Watts, 1987; Zeichner, 1992; Zeichner \& Liston, 1987) and preservice teachers' personal histories and preconceptions of teachers, students, teaching, schools, and learning to teach (e.g., Connelly \& Clandinin, 1988; Feiman-Nemser \& Buchmann, 1987; Knowles \& Holt-Reynolds, 1991; Weinstein, 1989; Zeichner \& Gore, 1990) and within the practical context of our experiences as tcachers, tcacher cducators, and researchers.

We begin with a look at preservice teachers' images and expectations of self as teacher formed with the influence of prior experiences and interactions with people and texts during participation in formal programs (i.e., through course work, discussion, and other interactions). Next, we examine preservice teachers' disillusionments in relation to their understandings about what it means to teach and be a teacher. Finally, we focus on school contexts to explore discrepancies between preservice teachers' expectations and the realities of schools, classrooms, and students. We consider strategies and approaches to facilitate preservice teachers' preparation for learning in the field which take into account their expectations and the realities of the field. By way of conclusion and discussion we assert that greater attention needs to be paid to preparing preservice teachers for the realities of field experiences and to helping them make sense of their encounters in light of their prior expectations.

Images and Expectations of Self as Teacher: Influences of Prior Experiences

Those entering formal preservice preparation programs bring with them beliefs, attitudes, ideals, influences, and expectations developed over years of life experience and exposure to a 
wide variety of teaching-learning situations and contexts. They often have firmly rooted images of themselves as teachers and high ideals and aspirations about teaching. To illustrate, we present two narrative accounts written by preservice teachers early in their preparation programs and prior to their re-entry to schools for field experiences. They represent the kind of highly idealized and contrived images and expectations of self as teacher that preservice teachers typically bring to formal teacher preparation.

As I envision myself as a teacher, I see myself standing in front of the classroom where the seats are arranged in a semi-circle allowing students a clear vision of the [chalk] board, and discussing with students the lesson I had prepared for the day. I see myself using plenty of visual aids, writing important points on the board, repeating myself several times, and waiting to receive responses or questions from the class. The learning environment is created by the students themselves, since they are the ones who need to have a pleasing atmosphere in which to learn and study. It is bright but not distracting, cozy enough so that the students do not feel that they are in a strange place, and intellectually stimulating so that they are always being exposed to something "educational."

I am not the type of teacher who stands in front of the classroom monotonously lecturing; rather, I share knowledge with my students by providing many examples and stories, and encouraging as much student interaction as possible. I am approachable and open-minded; students are not afraid to ask me questions or scared that I may reject their thoughts. I am confident while teaching, appropriately prepared and ready to present material in an organized manner, and able to respond to questions or doubts students have concerning the material. I give my students the $100 \%$ effort that I also expect from them. (Priya Nagaraju).

Ideally, I see teaching as a variety of activities that convey to eager students an understanding of their universe. Attendance is not taken because the students enjoy class so much. Administrative details never take more than a moment. Disruptions and discipline problems are nonexistent because all of the students really want to learn. Frequent exploration activities are noisy and full of discussion, action, and interest. Lectures are quiet and filled with subdued anticipation but frequented with relevant, in-depth questions. Lively discussions and debates bring up intense ethical questions and open, sensitive dialogue is common. The students see the teacher as a mentor, one helping them learn and learning along with them. The administration is super supportive and takes an active interest in the teacher's programs. Supplies are readily available and materials virtually unlimited. Finally, at the end of the day, the teacher is tired from truly appreciated effort, happy with the day's accomplishments, enriched in knowledge, and emotionally uplifted by the enrichment of others and self. (Kevin Queen)

Though each is unique, the nature of these images is not unusual. But, because preservice teachers' images are usually either composites of past experiences or based on single outstanding and memorable individuals or events, they usually do not hold up in real contemporary contexts. They are images frozen in time and context and lacking animation, much as a photographic representation. Often, these images shatter against the hard realities and complexities of schools, classrooms, and day-to-day teaching.

It is well documented that preservice teachers strive to enact or play out their personal images of teaching despite contextual realities which are often at odds with them (e.g., Aitken \& Mildon, 1991; Bullough, 1991; Cole, 1990; Knowles, 1992; Knowles \& Hoefler, 1989). One explanation for such persistence is found in the literature exploring the influence of personal history on lcarning to tcach. Since Lortie (1975) proclaimed a need for attention to the role of prior experiences in the process of becoming a teacher, a field of investigation on the topic has grown. Now, it is quite widely accepted that formal teacher education has an important but secondary influence on teachers' thinking and practice; the latter being indelibly imprinted by life, school, and career experiences prior to entry to formal programs of teacher preparation. ${ }^{2}$

Wright and Tuska (1968) advanced a "childhood romance theory of teacher development" which suggests a strong influence of significant others (usually adults) during childhood on teachers' self-image and practice. Ross (1987) argues that preservice teachers select attributes and practices of their own former teachers and synthesize them into an idealized image or model of the teacher they want to become. Crow's

\footnotetext{
${ }^{2}$ For a comprehension sense of the work conducted in this area, see literature reviews conducted by Zeichner and Gore (1990) and Kagan (1992), and ongoing work by Clandinin and Connelly (e.g., Clandinin, 1986; Connelly \& Clandinin, 1988), Butt and Raymond (e.g., Butt \& Raymond, 1987; Butt, Raymond, McCue, \& Yamagashi, 1992), Goodson (e.g., Ball \& Goodson, 1985; Goodson \& Walker, 1991; Goodson, 1992; Goodson \& Cole, in press), and Knowles (1988a, 1988b, 1992, in press).
} 
(1987) case study of four preservice teachers provides additional evidence of the biographical influcnce on individuals' beliefs about teaching, education, and practice. The ways in which the preservice teachers in Crow's study viewed themselves-their "role identities"-were strongly linked to their biographies.

Building on Crow's study, Knowles (1992) linked success and failure in beginning teaching practices both to early field settings and to role identities and images of teaching formed over years of prior educational experiences in family, classroom, and school settings. In his study, preservice and beginning teachers with strong role identities (rooted in positive formative life and school experiences) had less difficulty coping with challenging situations and contexts and experienced more success than did those with weak role identities (rooted in negative formative life and school experiences). Aitken and Mildon (1991) report similar findings. They note that those who entered field experiences with images of teaching and teachers more congruent with the realities of classrooms were able to adjust to and learn from the problems they encountered.

Mcneely and Mertz (1990) suggest that preservice teachers' disillusionment is related to idealized notions of students and classrooms communicated during course work. A preservice teacher in our research supports this notion:

Part of my confusion stems from taking university
ideals too literally. After years of being told to never
use work sheets, eschew the test, and to be novel,
innovative, and fascinating at all times I conclude that
I have planning paralysis.... I am worried about
management, puzzled by grading, and confused by the
workings of schools. And then, being the perfectionist
I am, I expect to stand up and dazzle their little minds
with original thoughts. (Steve Bruno)

Whether preservice teachers' misconceptions of the work of teachers and teaching rest in prior personal experience, university course work, or both, the outcomes are potentially dysfunctional and can lead to mis-educative experiences in the field.

The ideas and images about tcaching that preservice teachers bring to formal teacher education programs are deeply etched on their perceptual lenses. But, because such preconceptions were formed based on limited experience and understanding of what teaching is really all about, it is important for preservice teachers to, as Buchmann (1990) says, "break from experience," that is, to go beyond habitual interpretations of persons and events to make more open and informed educational judgments and decisions. The challenge is to find ways of understanding early influences on developing and emerging practices. As Feiman-Nemser (1983) states:

\begin{abstract}
The likelihood that professional study will affect what powerful carly cxpcriences have inscribed on the mind and emotions will depend on its power to cultivate images of the possible and desirable and to forge commitments to make those images a reality. (p. 154)
\end{abstract}

\section{Preconceptions of What it Means to Teach and $\mathrm{Be}$ a Teacher}

Disillusionment also comes about as individuals become more cognizant about what teaching and being a teacher are really all about. In Cole's (1985) study, for example, preservice teachers' disillusionment was grounded in discoveries about the nature of teachers' work. Some student teachers found that they were at odds with the reality of the work and role of teacher. They did not like elements of the profession they were about to enter.

Past personal experiences of schools and teaching, combined with relatively simplified or stereotypical depictions of the profession in the mass media, contribute to the formation of inappropriate images and inadequate expectations of teaching as a career and profession (see, Barone, 1992; Shack, 1965, chap. 2). For example, in the U.S.A. teacher education is seen as easy to gain admittance to and intellectually weak (Lanier \& Little, 1986). (This perception about easy admittance is not widely held in Canada where, in many universities, the admissions standards are so high that only a very small percentage of applicants is accepted.) And, as Book, Beyers, and Freeman (1983) assert, about a quarter of those entering teacher preparation programs in the U.S.A. maintain that there is little they need to learn to become successful teachers because they already have pedagogies in place in their thinking.

With such limited and narrow understandings of what teaching is all about it is no wonder that preservice teachers very often experience sur- 
prised confusion upon discovering the multifaceted and multi-layered nature of teaching. The following three accounts are illustrative:

Wow! The first day of school. It blows my mind how much a teacher needs to think through and organize before the students even step foot in the room. I am going to write down some planning needs so that I will remember things that I will want to hang up in my own class (calendar, weather graph, birthday cakes, etc.). I want to make attendance cards and a job poster. I need to think how I arr going to have students organize, hand in, and pick up papers and how I am going to keep track of their progress. I have to think of a grading system that is consistent. I have to think of how I want to arrange the desks and the lab areas. I have to think of what method I am going to use to get the students' attention ... (Renee Buscho)

Growing up, even in my collegiate career, I considered teaching to be a job that, after a few years, becomes an easy route to a paycheck. I have discovered that teaching is a profession that requires not only skill but a tremendous amount of time, patience, and intuition. For example, in preparing to teach a two week unit plan about tobacco and alcohol, I prepared a month in advance and still was left with loose ends at the last minute. I now have more respect for those who have chosen to take upon themselves the awesome responsibility of being educator, facilitator, and loci parentis. (Terry Ingram)

Teachers are expected to be so dynamic, meaning that they have to keep so many things under control, bring interesting material to students, be effective in using a variety of teaching methods, understand differences between students, incorporate different resources, consider diverse perspectives and the diversity of students backgrounds and ethnicities, construct curriculum, and be understanding and flexible. And this list barely begins to cover what people expect. The prospect of being a teacher is at once exciting and frightening. (Jeanne Worthen)

The relatively recent shift to a qualitative approach to rescarch on teaching has resulted in an increase in descriptive research that more accurately depicts the complexity of teaching and life in schools and classrooms (see, e.g., Britzman, 1991; Bruckerhoff, 1991; Clandinin, 1986; Cohen, 1991; Freedman, 1990; Kidder, 1989; McLaren, 1986). Also, awareness of the complexity of teaching has been raised through studies such as Schoolteacher (Lortie, 1975), a sociological study of the teaching profession in the U.S.A., and Teachers at Work (Johnson, 1990), an examination of teachers' work with a focus on the context of teaching as it is experienced by teachers. And, in an analysis of "the cultures of teaching," Feiman-Nemser and Floden (1986) articulate the complexity by making a helpful distinction between the job of teaching and the work of teaching. But, because educational literature is not widely read by those not already in the profession, few preservice teachers enter formal preparation programs with either comprehensive or realistic understandings about teaching. Also, according to Zeichner and Gore (1990), studies of preservice teacher socialization "have rarely taken into account the character and quality of institutions in which teacher education programs exist" (p. 336); therefore, there is limited opportunity, at least as evidenced in the programmatic and research literature, for preservice teachers to understand the complexity of learning to teach within the context of various institutional and programmatic demands and influences.

Until recently, the complexity of teaching and being a teacher were not explicitly addressed in most preservice preparation programs. Preservice teachers had limited opportunities to develop a fuller understanding of what it means to teach and be a teacher. As Lasley and Watras (1991) observe:

\begin{abstract}
The preoccupation with the knowledge base and with accountability has encouraged the adoption of simplified pedagogy and educational reductionism... Teaching is emerging in the popular educational literature as a linear process.... Preservice teachers learn the steps, and then during... field practices they are evaluated on those skills. The linear approach is reinforced by the reliance school districts place on ... packaged approaches. .. Even in teacher education programs ... students [for the most part] go into field placements and work with teachers who possess the "right" method. (p. 6)
\end{abstract}

Thus, they go on to argue, preservice teachers have little opportunity to understand and appreciate the complexity of teaching and schooling, and to treat teaching as more than a narrow, applied field. Such a confining perspective focuses exclusively on the technical and procedural elements of teaching and forgoes developing understandings of the complex nature of the profession and its context.

Some preparation programs have been redesigned to take into account and build on prospective teachers' preconceptions or personal theories of teaching and learning. Erickson and MacKinnon (1991), for example, in a program of 
research focused on the development of a reflective practicum in science teaching, describe how, with guided supervision, preservice teachers reconstructed their understandings. Over the course of one year, Laboskey (1991) observed preservice teachers become more reflective and more able to challenge their prior beliefs and knowledge through journal keeping. In a study of prior beliefs and conceptual change conducted by Hollingsworth (1989), some preservice teachers were able to modify some of their preconceived ideas about classroom instruction in part because they were encouraged by their cooperating teachers to confront their beliefs. In another study in which opportunities for examination of and reflection on prior beliefs about teaching writing were provided to preservice teachers within the context of their field experience, those teachers also were able to reconstruct their preconceived ideas (Florio-Ruane \& Lensmire, 1990). Zeichner and Liston (1987) discuss personal and contextual factors that facilitate and constrain the realization of goals in a reflective teacher education program intended to "help student teachers become more aware of themselves and their environments in a way that changes their perceptions of what is possible" (p. 25).

\section{Fxpectations and Realities of Students, Classrooms, and Schools}

For many preservice teachers, re-entry to schools delivers a mild to severe shock when they find that their images of students, teachers, and schools are inappropriate. Quite frequently, preservice teachers have inappropriate or unrealistic expectations about the students they are to teach (Gomez \& Comeaux, 1990; Kagan, 1992), perhaps a result of limited knowledge of those students (Florio-Ruane \& Lensmire, 1990). Some of these discrepancies rest in a commonly held perception that the students preservice teachers will encounter will be like they were as students (Hollingsworth, 1989; Knowles \& HoltReynolds, 1991). Coupled with "entering" viewpoints about what is needed to become a teacher, these distorted perspectives about students have some bearing on the gap between expectations and realities that many preservice teachers encounter as they enter schools again.
We present a series of excerpts from narrative accounts to illustrate some of the many sources of disillusionment for preservice teachers. In the first two, Sadie describes how her idealized image of students, influenced by her own experience of school, was challenged in her field experience, and Cynthia relates her overall experience of shock and disillusionment upon her re-entry to schools.

I always thought that teaching would be like a fairy tale. All the children would have nothing but respect for their teacher. They would sit there and listen when the teacher was talking. There would only be a few children who were troublemakers; the rest would be angels. They would want to be at school and they would really enjoy learning. I guess I was assuming that all the kids would be like I was in elementary school. I do not remember classrooms being so chaotic when I was younger. I thought it would be so easy to plan what you were going to do each day. I never realized how much would be involved in getting students motivated and keeping their attention. Obviously I was misled by my assumptions. (Sadie Rabinowitz)

The first time I set foot in the school I was terrified. I was transported back 25 years to my own junior high school days. I was suddenly shocked into reliving all the things I had hated about school: all the frustration, loneliness, injustice, boredom, and resentment. For a while I thought there was no way I could be part of that system. What I saw and sensed was so contrary to everything in which I believed.

The school I was assigned was not what I had wanted it to be. The structurc of the classes, classrooms, and rules were too restrictive, too narrow. The kids were forced into a mold that too often did not fit. The physical and administrative structures were counter-productive. I felt that the school was really wasting students' time. I resented the inability [of teachers] to give students individual attention, and the necessity of constant attention to discipline problems. (Cynthia Hohnke)

Field experiences often provide preservice teachers with their first opportunity for a closeup view of staff relationships and school culture, at least from a teacher's perspective. For Renata and Steve, exposure to this facet of being a teacher was a source of disillusionment.

I often thankfully consider my friendship with and trust in my fellow student teachers, especially when I think of them in comparison with the high school faculty. The words "catty," "fearful," "uncooperative," and "down right mean" often come to mind when I think of the faculty. Various cliques and individuals vie for power and prestige by making 
others look bad or inefficient. Some teachers in the school hate this atmosphere and avoid contact with [opposing] fellow faculty members whenever possible. The net result is rather unwholesome and unproductive for promoting the best academic and educational atmosphere. So much for the idea of professional people working together to improve the quality of education. "Career ladders" seem to have added to the competition among teachers. Is this the best approach to developing career professionals? (Renata Lalonde)

The focus of staff meetings and staff room discussions are twofold: in the staff meetings, faculty inevitably center on school functions; in the staff room they focus on student control. The purpose for which teachers ostensibly are hired-instruction-is glaringly absent in conversations. Staff room gripe sessions might serve the purpose of letting off steam, allowing teachers to stay sane, but something seems amiss at staff meetings. Maybe I am still too idealistic and would like to concentrate on teaching and not "dress-up day" or whether boys should wear earrings - Christ, isn't that one battle we could avoid? Let the boys make their statement. That is what growing up is all about. Is this stress on order and appearance common to all schools and all principals? In this school there are expensive planter boxes in the foyer while some classes lack textbooks. (Steve Bruno)

Joanna and Josephine had the unfortunate experience of being placed with cooperating teachers whose practices contributed to a miseducative and frustrating field experience.

I expected that the teacher with whom I was placed would be worthy of university approval as a cooperating teacher but I did not feel that in reality this was true. In fact, I felt she was a good example of what a teacher should not be-a non-planner, a dittomaker, somebody ignorant of most of the recent theories I had learned about in courses. I was placed with a teacher I thought was lazy and the experience was very disillusioning - I felt it was a very expensive loss in terms of experience. (Joanna Frank)

I found myself with positive anxiety about teaching. I could hardly wait to meet my students and get started. These positive feelings became laced with fear again after talking to one of my two conperating teachers. She spoke very negatively about the students-she had absolutely nothing positive to say. After hearing her talk about her students to me and to other faculty members, and hearing comments about these students from other teachers, I was convinced they were "animals." Every example the cooperating teacher pointed out in class seemed to prove her point; everything "bad" that they did was highlighted, and it became impossible for me to see anything good about them. Even when I saw something good, she countered it with so many examples that I soon forgot the good things. I was terrified to teach the students. (Josephine Figuero)
Gabrielle provides an example of how the sometimes rigid nature of one's perceptual boundaries can interfere with learning. Her firmly established preconceived ideas and expectations about how a classroom should look and operate set up a conceptual barrier which took quite a while to remove.

When I first walked into Mrs. Hindman's room, I hated it. I thought it was very dirty and disorganized. I felt that because Mrs. Hindman was not organized, she did not have a clear sense of her goals and objectives, nor of the capabilities of her students. Now I know that this was a false assumption. At the beginning of my preservice teaching, I was too uptight, too rigid. I had certain ideas of how I thought a classroom should be run and Mrs. Hindman did not fit my expectations. Because of the discrepancy between her classroom and my expectations, I was forced to step back and re-evaluate exactly what teaching is all about. Unfortunately, it took me half of the semester to come to this realization; I spent the first half of the semester focusing on what was going wrong in the classroom. I was so set on my personal way of doing things that I was blinded to all of the good things going on around me. Through observing the students' inleractions with Mrs. Hindman and [by exploring the operation of] the classroom, I found, in fact, that her room was an effective setting for children to learn and her methods seemed to work well with the students. (Gabrielle Tuchow)

Case studies of preservice teachers' experiences upon re-entry to schools (e.g., Britzman, 1991; Crow, 1987; Knowles, 1992) evidence how firmly grounded in personal history are preservice teachers' expectations and understandings of schools, teachers, teaching, and students. Because such understandings form the foundation for developing practice and because they usually are incomplete and may derive from negative experiences, these and other similar studies stress the importance of helping preservice teachers make explicit for examination both their personal histories and preconceptions of teaching (see, also, Knowles \& Holt-Reynolds, 1991; Zeichner \& Grant, 1981). The idea behind this argument is that unexamined constructs are likely to remain unchallenged and therefore static. And, when preconceived images are at odds with realities presented in field experiences, difficulties are likely to arise (Aitken $\&$ Mildon, 1991; Knowles, 1992; Knowles \& Hoefler, 1989).

Another clear illustration of this concept is presented in a study of 20 preservice English teachers (Zitlow, 1986). Reflecting on their re- 
entry to schools, they described teachers, students, and classrooms as "real eye openers" when viewed in comparison with their own experiences as students. Preservice teachers who, in their field experiences, gave limited priority to learning or who felt constrained by pressures and demands of the school organization and culture, had themselves attended dysfunctional high schools or felt that they were not "winners" in competitive high schools. One person who had attended what he perceived to be a challenging and competitive high school found the "apathetic, sleeping" students to be a rude awakening. On the other hand, preservice teachers who reported having repeated chances, as students, to make decisions about their own learning, often facilitated by individual outstanding teachers, held more comprehensive learning priorities for their future students. Other examples of difficulties encountered as a result of preservice teachers expecting students to be like they were are found in Hollingsworth (1989), Knowles and Hoefler (1989), and Knowles and Holt-Reynolds (1991).

Colleen captures the sentiment of many preservice teachers whose ideals are shattered during field experiences.

At such an early age, school serves to shut down the finest, purist qualities. Creativity and imagination are thwarted and controlled to fit into an adult's conception of appropriateness. It seems that children are naturally curious and delighted to make discoveries and be creative-many adults end up striving to recreate or search for the very qualities that all of us have intuitively as children, and learn so early to hide. I have been surprised (shocked is better) to see what the implicit curriculum contains: "Don't help a classmate;" "Cover your work;" "Don't cry if you are hurt." I am hesitant about entering the field as a fulltime teacher and continuing that process while thinking (hoping) that it doesn't have to be that way. (Colleen Presswood)

\section{From Disillusionment to Dysfunction}

Working in field placements is typically the first time many preservice teachers are seriously tested as they try on their new roles as nearly fulltime teachers. As might be expected, some of them come up short. Given the complexity of learning communities, the diversity of students and contexts, the demanding nature of teaching, the potential for mismatches in placements and personnel, and the overall artificiality of field experiences it is little wonder that some (albeit a relatively small minority) preservice teachers experience serious difficulty. Such individuals often cannot meet the sometimes unrealistic expectations that they and others have placed on them. They are overwhelmed by the intricacies of schools. They are burned by the pace, complexities, and circumstances of classroom life. They are overcome with the prospects and problems of facilitating learning within the contextual realities of contemporary classrooms and schools.

Needless to say, achieving less than expected is disappointing, especially for individuals who have set their sights on becoming teachers, participated relatively successfully in the university components of formal teacher preparation, and put considerable financial and other resources into becoming teachers. The reality is, though, that some preservice teachers find that once they are thoroughly immersed in the culture of schools and classrooms working with teachers and students, they are not temperamentally or otherwise suited to performing the tasks and responsibilities of teaching. And so, some prospective teachers counsel themselves out of preparation programs for a variety of reasons, including their perceived potential for and actual poor performance in field placements (Guyton \& McIntyre, 1990; Knowles \& Sudzina, 1991; see, also, Knowles \& Hoefler, 1989).

In the following account, a preservice teacher tells how her idealized images and expectations of herself and of teaching and schools eventually led to her withdrawal from student teaching. Her disillusionment became dysfunctional.

\footnotetext{
What I learned was not at all what I had expected. I had thought that I would figure out a way to bring to life all the wonderful theories I had studied. I had aimed to figure out a system for being so organized that the class would always run smoothly. I had aspired to use creative ideas to make every lesson interesting. I was determined to find a way to reach every student. What I actually discovered was that I had set too many high expectations, causing myself to burn out before I really got started. It was an extremely painful yet important lesson for me to learn. I naively plunged into student teaching expecting to accomplish goals that teachers with years of experience are still striving to attain. I was so disillusioned, I viewed not being perfect as failing. I had a lot to learn about my ideals, philosophies and the realities of teaching. When I began to realize that I could not possibly live up to those expectations, I panicked. I
} 
became paralyzed. Something inside of me forced me to believe that it was better to not even attempt to teach rather than to risk teaching poorly. So, I painfully resigned as a student teacher, stifling my lifelong pursuit to become a teacher.

After I discontinued my student teaching, I was graciously given the opportunity to finish out the semester observing other teachers and their student teachers. I quickly noted that none of the teachers seemed to live up to all of the expectations that I had set for myself. I puzzled over why they did not seem to get discouraged or feel guilty about their performances, as I had. I began to wonder if I had been too harsh a self-critic. My observations forced me to reevaluate what was realistic to expect from a teacher. 1 compared my past performance to that of the student teachers whom I observed. The only significant difference that I noted was that they were not afraid to keep trying. I realized that if I was to ever teach that I would have to learn how to strive to accomplish my goals while simultaneously allowing myself to be satisfied with less than perfect results. (Renee Buscho)

Compared to other areas of teacher education research, there is little work available which focuses on failure in field experiences or student teaching (Guyton \& Mclntyre, 1990). Nevertheless, within the very small body of research which directly addresses failure, numcrous factors are cited as contributing to preservice teachers' poor performance in field settings. There are four clusters of factors. One cluster of factors relates to curriculum and instructional matters. Because of the technical nature and specific focus of the factors in this group, their relevance to this paper is indirect; we consider the three other clusters (see, Knowles \& Sudzina, 1991 for a discussion of these factors).

The second group of factors centers on preservice teachers' development of a sense of self as teacher: role conflict or the discrepancy between the idealized role and the role demanded by the reality of the teaching situation (Knowles, 1988a, 1988b, 1992; Knowles \& Hoefler, 1989; Schwab, 1989); role ambiguity associated with little sense of how they want to act or, conversely, how they do not want to act in the classroom (Knowles, 1988a, 1988b, 1992; Knowles \& Hoefler, 1989; Schwab, 1989); and personality traits not conducive to optimal teaching and classroom leadership (Knowles, 1988, 1992; Knowles \& Hoefler, 1989; Riner \& Jones, 1990).

Contextual factors make up the third group: isolation and lack of collegiality (Schwab, 1989); inappropriate immediate role models (e.g., the cooperating teacher) (Knowles, 1988a, 1988b; Knowles \& Hoefler, 1989); lack of understanding of the institutional culture as associated with setting (e.g., rural, urban and inner city, or suburban), orientation (public or private), philosophy (traditional or non-traditional, teachercentered or student-centered); mismatch of grade level placement with preparation; and, lack of confidence when dealing with the cognitive and social maturity levels of students (Knowles \& Sudzina, 1991).

Patterns of past performance and elements of personal histories are a fourth cluster of factors which may also contribute to individuals' inabilities to master successfully the expectations of classroom teaching during field placements: inconsistent levels of participation and performance in university course work (Pape \& Dickens, 1990); an unwillingness to ask for help (Pape \& Dickens, 1990); a lack of time and resource management and role overload (Goodman, 1987; Pape \& Dickens, 1990; Schwab, 1989); physical or mental dysfunction (Riner \& Jones, 1990); and, previous difficulties in educational settings (Knowles, 1988a, 1988b).

Elements of the latter three categories have direct relevance to the focus in this paper. Although we are not suggesting that experiences of disillusionment necessarily lead to failure or withdrawal from student teaching, we do believe that, for those who continue, such experiences left unaddressed encourage the development and adoption of skills merely to survive within the school system and within classrooms, and thereby perpetuate the status quo.

Perpetuation of the status quo by new teachers comes about, it seems, from less than solidly grounded understandings of the roles and responsibilitics of teachers and the rclationship between theory and practice. Challenges to those understandings emerge when individuals step back and question the very foundations of takenfor-granted personal perspectives and preconceptions, as well as the activities, functions, and structures associated with the roles and responsibilities of teachers and the sites in which teaching takes place. These challenges are most likely to take place once experiences of the field are laid alongside early experiences of schools, classrooms, and teachers, as well as experiences in the university context. The ways in which preservice teachers make sense of their field experiences is, 
therefore, profoundly important for their future actions as teachers.

Taken to the extreme, and given that prior experiences figure prominently in preservice teachers' thinking, if these individuals are disillusioned to such an extent that they are not able to break the bounds of the conceptual frameworks about teaching with which they entered formal programs of preparation, they are in danger of teaching as they were taught themselves as pupils. Thus, at this point in their professional preparation, the power of personal histories as evidenced in prior experiences is likely to outweigh the potential potency of informed professional judgements.

We turn now to consider the following questions: "What can we as teacher educators learn from the experiences and articulated expectations of preservice teachers?" and "How can we better assist preservice teachers in their preparation for field experiences and the realities of teaching?"

\section{Understanding Expectations and Realities of Field Experiences}

From an analysis of over 40 studies of learning to teach and existing models of teacher development, Kagan (1992) developed a way of explaining teacher development that validates and helps to explain the learning to teach process as it is experienced, taking into account its complex and personal nature. According to Kagan, growth consists of at least five components: a developing awareness of initial and changing knowledge and beliefs about pupils and classrooms; a reconstruction of idealized and inaccurate images of students and a reconstruction of early images of self as teacher; a shift in attention to students and instruction upon resolution of one's own professional identity; acquiring and becoming comfortable with standard classroom procedures; and, growth in problem-solving skills. When and how development takes place, according to Kagan, depends on at least three factors: the novice teacher's biography or personal history (clarity of image of self as teacher and readiness to acknowledge and accept that beliefs and images are inaccurate); the configuration of the preservice teacher education program (including the amount of time spent in educational contexts); and, the contexts in which student and beginning teaching occur (nature of pupils, beliefs of and relations with other teachers, availability of materials, principal's beliefs, and relationships with parents). Of particular importance are the relationship between preservice and cooperating teachers and the degree of autonomy afforded by a principal. In short, Kagan (1992) acknowledges that, "The practice of classroom teaching remains forever rooted in personality and experience and that learning to teach requires a journey into the deepest recesses of one's self-awareness, where failures, fears, and hopes are hidden" (pp. 164-165).

Kagan's model holds promise for program design. We propose two primary methods for facilitating learning from prior experiences and preparing for field experiences: gathering internal information through autobiographical writing, and gathering external information through extensive explorations of contexts and people within those contexts. ${ }^{3}$ These methods are rooted in an ongoing process of reflexivity and inquiry and consistent with Kagan's perspective on teacher development.

\section{Gathering Internal Information Through Autobiographical Writing}

Autobiographical writing in preservice teacher education is "rooted in the process of coming to terms with oneself" (Knowles \& Holt-Reynolds, 1991). Through personal or life history accounts, journal keeping, explorations of personal metaphors, and reflective accounts of practice preservice teachers are provided ongoing opportunities to make explicit for examination their preconceived ideas, images, expectations, and developing conceptions of teaching and being a teacher. In the process of becoming aware of self, individuals recognize the often circumlocutious trails taken in the process of becoming preservice

\footnotetext{
${ }^{3}$ For a more extensive description of these methods, see Knowles and Cole with Presswood (in press). Sceptics often argue that such reflexive/inquiry practices are too time consuming given the "content" demands of teacher preparation programs. As we argue later, to do other than facilitate the development of reflexive practices may be to prepare new professionals to do little more than maintain the status quo.
} 
teachers. In so doing, they acknowledge the primacy of experience in developing perceptions and beliefs about practice and conceptions about what it means to be a teacher.

Autobiographical writing in the period of formal learning about teaching is valuable for several reasons. First, and perhaps foremost, is the value of record keeping. Its value rests on the premise that individuals come to formal teacher preparation programs with an array of experiences in schools and other learning places. Such a record is a useful place for prospective teachers to begin to frame their present orientations and trace their developing thinking, important in forging ongoing professional development.

Second, autobiographical writing is a powerful vehicle for enhancing learning. Writing about philosophies, theories, principles, and skills related to teaching and education may help preservice teachers reveal the extent of their learning. It is also a mechanism and medium for sharing experiences with others, and learning from others through writing.

Third, autobiographical writing, if shared with others, provides a window into preservice teachers' thinking. In particular, it may holp teacher educators more appropriately meet the learning needs of prospective teachers by providing insights into preservice teachers' thinking, reactions to learning contexts, responses to guidance, instruction, field placements, and the program in general. It is also a useful way for some preservice teachers to alert others to the difficulties faced in field placements.

Other values of autobiographical writing have to do with its usefulness for personal inquiry and "formal" research. In the first case it presents opportunities for generation of internal information for preservice teachers' own use; in the second case, and under certain conditions, as data for other researchers.

Personal history accounts. Each prospective teacher possesses a personal history that is rich and intensely interesting. By personal or life history accounts we mean stories of experiences of learning in formal and informal settings - in families with parents and others, and in schools and other institutions with teachers, and so on-and the meanings attributed to those experiences. Personal history accounts represent, in a sense, the informal reflection that occurs as prospective teachers recollect, ponder, and interpret various education-related experiences. Like formal or published autobiographies, diaries, and journals, and artistic expressions of various kinds (such as poetry and creative writing, painting, and sculpture, as well as crafts), personal history accounts are a distinct form of personal documents.

For the most part personal histories are private, mental constructs; however, most individuals possess observable evidence of elements of their personal histories: photographs, report cards, the outcomes or products of school assignments, creative writing efforts, artworks, craft works, old textbooks and readers, trophies, school yearbooks, even scars. These artifacts of experience may serve to jog memories about particular experiences and perspectives which have shaped individual's thinking about becoming a teacher. Although writing a personal history account may, for some individuals, be a difficult and perplexing task-especially if elements of prior experiences are confronted which are contradictory to elements of present lives, career directions, or philosophical orientations of tcacher cducation programs and school placements - writing a personal history account is likely to assist professional development of preservice teachers because it acknowledges cumulative learning about the profession.

In writing about experiences associated with learning, schools, classrooms, and teachers, preservice teachers can make known implicit theories, values, and beliefs which underpin their thinking about being a teacher. It can also be a basis for continuing conversations about the nature and substance of their thinking about becoming a teacher.

Journal writing. Not only has journal writing gained popularity as a pedagogical tool in school classrooms over the last decade or so, it has also become central to many university courses. The power in journal writing within the context of learning to teach is primarily located in its usefulness for recording reactions to schools, classrooms, teachers, and students. It also offers a place to explore the planning and outcomes of curricular, instructional, relational, and classroom management activities. It is a particularly good venue and medium for preservice teachers to record their reactions to some of the pervasive 
and central issues surrounding education, such as racial and gender inequities, financial and resources inequities, political and social influences and demands, issues of empowerment, authority, and autonomy, roles and influences of teacher's unions on learning, and so on. The scope of their journal writing is only limited by the contexts in which they work, the timc available, the foci, and their energies.

One form of journal writing-dialogue or interactive journals - is, for many individuals, especially suited to the purposes of teacher preparation. We make this claim because the notion of a dialogue or ongoing conversation and interaction with a more experienced colleague or peer seems to follow naturally the process of writing about prior experiences and preconceptions of teaching-as one might focus on in writing a personal history account.

Explorations of metaphors. Attaching language to or finding appropriate ways to communicate about teaching is often difficult. The use of figurative or metaphoric language is helpful both as a way of communicating about teaching and as a way of enhancing personal understanding of teaching. Metaphors provide a way of carrying ideas and understandings from one context to another so that both the ideas and the new context become transformed in the process. When this notion is applied to teaching we have a way of understanding and representing teaching that is more personally meaningful. Pcrsonally generated metaphors of teaching give meaning to the abstract and elusive aspects of classroom practice. They can capture and communicate the very essence of one's perspective. As vehicles of thinking, metaphors are coherent ways of succinctly organizing and representing thoughts about particular subject matters, activities, or theories. At another level, metaphors are linguistic representations of mental images which reflect personal perspectives; therefore, one of the ways in which preservice teachers can explore some of their perspectives on teaching is through metaphor. And, as preservice teachers expand their thinking about being teachers and working in schools, their metaphors may change to reflect their moving mental landscape of practice.

Professional development summaries. The foundation of professional development summaries are records of emerging and developing thinking about being a teacher. Journal records, a pcrsonal history account, class assignments, practice teaching plans or logs, videos and perhaps photographic accounts, and other recorded activities provide the evidence and, in turn, the substance of professional development summaries. In a sense, these summaries are the continuation of personal history accounts. They represent ongoing analyses of the professional experiences associated with participation in a formal program of teacher education and data for future professional development summaries. Presuming preservice teachers develop these summaries at various points along the continuum of their formal preparation to teach, these summary narratives build upon each other into a coherent critique and record of professional development.

Clarifying and understanding personal constructs through various forms of autobiographical writing can provide preservice teachers with considerable insights into themselves as teachers and into their emerging practice. Emphasis also needs to be placed, however, on exploring educational contexts and people within those contexts.

\section{Gathering External Information Through Inquiry}

Borrowing the research tools of the anthropologist, preservice teachers can engage in in-depth "ethnographic" inquiry ${ }^{4}$ by engaging in periods of focused participant observation in classrooms, schools, and communities, by conducting informal and formal interviews or conversations with students, teachers, school and district administrators, non-teaching staff, parents, community members, and members of special interest groups, and by collecting documents or artifacts which provide additional information about the school, district, and community. Developing a

\footnotetext{
${ }^{4}$ We use the term "ethnographic" loosely to refer to the methods of the field anthropologist, namely participant observation, interviews, and document or artifact collection. The focus on understanding culture or the lengthy period in the field are not implied in this context.
} 
focus of inquiry and accessing information which originates from outside or external sources has great potential for informing preservice teachers.

Participant observations. When engaging in the activities of field experiences within the culture of schools and classrooms preservice teachers are at the same time both participants in the culture and observers of that culture and its participants-a unique opportunity to engage in school-based inquiry projects.

Interviews. There are many people from whom preservice teachers may gain useful perspectives about a whole range of topics pertinent to their professional development. Interviewing is one potentially rewarding and informative activity where people who have "insider" knowledge help preservice teachers learn and understand about the elements of the school, group, or culture.

Collecting documents or artifacts. As preservice teachers participate in field experiences and explore aspects of the school and student cultures, various kinds of documents may prove useful in making sense of their experiences. School district offices, school administrators, teachers, students, parents, and the community including the news media produce voluminous amounts of printed matter-policies, rules, guidelines and forms of various kinds, statements of core curriculum, curriculum materials, school newspapers and newsletters, community newspaper articles, stories, and photographs-which may provide additional insight into the state and workings of the school community. Documentary evidence will help "fill in the blanks" or explain some of the findings from the other forms of information gathering.

When preservice teachers combine the three external data gathering techniques into a study of some aspect of teaching and schooling they are essentially engaging in ethnographic research. ${ }^{5}$ Such research implies the activities of data gathering, analysis, and report writing, all with the intent of informing thinking about practice and practice itself.

\section{Consequences and Possibilities}

Most preservice teacher education programs place relatively little emphasis on the contextual realities of schools or on the complexity of teaching, focusing instead on what takes place between students and teachers within the confines of the classroom. In other words, most preservice programs concentrate almost entirely on teaching preservice teachers to teach; little attention is placed on helping them to become teachers. Consequently, preservice teachers are ill-prepared for the working realities of schools and for the overall complexities associated with teaching and the roles of teachers. Once in the field, returning to schools after an absence of anywhere from a few years to a few decades, it is not long before they experience surprise, dismay, disappointment, and disillusionment. Their idealized images of what teaching is all about shatter, almost on contact. It is not uncommon to hear comments from preservice teachers such as: "I don't remember the classroom being so....;" "I thought it would be easy;" "I never realized how much was involved;" "I assumed that all the kids would be like I was in school;" and conclusions like: "Boy, was I wrong!" and, "Obviously I was misled by my assumptions."

For most preservice teachers, a reintroduction to schools delivers a mild to severe shock of reality (Gaede, 1978), a shock that for some is sufficiently severe to terminate their teaching careers before they really had a chance to begin (see, Knowles \& Hoefler, 1989; Knowles \& Skrobola, 1992; Knowles \& Sudzina, 1991; Riner \& Jones, 1990). We do not mean to imply that discrepancies between expectations and realities necessarily lead to failure or career exit. We do point out, however, that because such discrepancies create barriers to seeing things in new or different ways, this often leads to less than optimum short- and long-term outcomes from field experiences.

Experience and a large body of literature on teacher socialization tell us that preservice and beginning teachers, once in the field either in practica or in classrooms of their own, often trade in their idealized images for more "realistic" representations of teaching. They become disillusioned by the realities of teaching and schools

\footnotetext{
${ }^{5}$ See Fontnote 3 . We say this only in the sense that they are utilizing ethnographic research techniques.
} 
and, generally speaking, respond in one of at least three ways: they leave teaching almost before they have begun; they learn "the system" and how to work within it - they merely survive; or, they work to uphold and practice their beliefs, convinced that they can and will make a difference. We are most concerned about those who choose either of the first two paths. (In saying this, we are assuming that preservice and beginning teachers' ideals are morally and otherwise sound.)

Those who prematurely leave and those who stay and adapt to situational realities do the most to perpetuate the status quo, to ensure that the schools and classrooms of tomorrow look much the same as the schools and classrooms of today and yesterday. We maintain that there are strong links between initial and ongoing teacher education and teacher development. Teachers who participate in preparation programs which focus mainly on the technical aspects of teaching or maintain a narrow view of what teaching and being a teacher entails, are likely to be illprepared to do other than maintain the status quo. And, programs which do little to prepare teachers to examine their own perspectives and their origins, as well as the contexts in which they will work and teach do likewise.

Thus, we advocate that preparation programs conceptualize teaching and being a teacher as complex processes and enterprises which must be considered holistically. An inquiry approach to teacher preparation based on internal and external information gathering methods as, for example, described earlier provides preservice teachers opportunities to engage in ongoing examination of self as teacher within the contexts of classrooms, schools, and the broader professional community. Habits and patterns of reflective inquiry are likely to afford greater congruity between idealized images and realities of schools such that beginning teachers may challenge and move beyond the status quo.

\section{References}

Aitken, J. L., \& Mildon, D. (1991). The dynamic of personal knowledge and teacher education. Curriculum Inquiry, 21, $141-162$.

Ball, S. J., \& Goodson, I. F. (1985). Teachers' lives and careers. London: Falmer Press.

Barone, T. E. (1992). A narrative of enhanced professionalism: Educational researchers and popular storybooks about schoolpeople. Educational Researcher, 21(8), 15-24.

Book, C., Beyers, J., \& Freeman, D. (1983). Student expectations and teacher education traditions with which we can and cannot live. Journal of Teacher Education, 34(1), 9-13.

Britzman, D. P. (1991). Practice makes practice: A critical study of learning to teach. Albany, NY: State University of New York Press.

Bruckerhoff, C. E. (1991). Between classes: Faculty life at Truman High. New York: Teachers College Press.

Buchmann, M. (1990). Beyond the lonely choosing will: Professional development in teacher thinking. Teachers College Record, 91, 481-508.

Bullough, R. V., Jr. (1991). Exploring personal teaching metaphors in preservice teacher education. Journal of Teacher Education, 42(1), 43-51.

Butt, R. L., \& Raymond, D. (1987). Arguments for using qualitative approaches in understanding teacher thinking: The case for biography. Journal for Curriculum Theorizing, 7(2), 62-93.

Butt, R., Raymond, D., McCue, G., \& Yamagishi, L. (1992). Collaborative autobiography and the teachers' voice. In I.

F. Goodson (Ed.) Studying teachers' lives (pp. 51-98). London, U.K.: Routledge.

Clandinin, D. J. (1986). Classroom practice: Teacher images in action. East Sussex, U.K.: Falmer Press.

Cohen, R. M. (1991). A lifetime of teaching: Portraits of five veteran high school teachers. New York: Teachers College Press.

Cole, M. (1985). "The tender trap?" Commitment and consciousness in entrants to teaching. In S. J. Ball \& I. F. Goodson (Eds.), Teachers* lives and careers (pp. 89-104). London: Falmer Press.

Cole, A. L. (1990). Personal theories of teaching: Development in the formative years. The Alberta Journal of Educational Research, 36, 203-222.

Connelly, F. M., \& Clandinin, D. J. (1988). Teachers as curriculum planners: Narratives of experience. New York: Teachers College Press.

Crow, N. A. (1987, March). Preservice teachers' biography: A case study. Paper presented at the annual meeting of the American Educational Research Association, Washington, DC.

Erickson, G. L., \& MacKinnon, A. M. (1991). Seeing classrooms in new ways: On becoming a science teacher. In D. A. Schon (Ed.), The reflective turn (pp. 13-36). New York: Teachers College Press.

Feiman-Nemser, S. (1983). Learning to teach. In L. Schulman \& G. Sykes (Eds.) Handbook of teaching and policy (pp. 150-170). New York: Longman.

Feiman-Nemser, S., \& Buchmann, M. (1987). When is student teaching teacher education? Teaching and Teacher Education, 3, 255-273.

Feiman-Nemser, S., \& Floden, R. E. (1986). The cultures of teaching. In M. C. Wittrock (Ed.), Handbook of research on teaching (3rd ed., pp. 505-526). New York: Macmillan.

Florio-Ruane, S., \& Lensmire, T. J. (1990). Transforming future teachers' ideas about writing instruction. Journal of Curriculum Studies, 22, 277-289.

Freedman, S. G. (1990). Small victories: The real world of a teacher, her students and their high school. New York: Harper \& Row.

Gaede, O. F. (1978). Reality shock: A problem among firstyear teachers. The Clearing House, 51, 405-409. 
Gomez, M. L., \& Comeaux, M. A. (1990). Start with the stone, not with the hole: Matching novice's needs with appropriate programs of induction. National Center for Research on Teacher Education, East Lansing, MI. (ERIC document No. 327541).

Goodman, I. (1987, April). Key fartors in becoming (or not becoming) an empowered elementary school teacher: $A$ preliminary study of selected novices. Paper presented at the annual meeting of the American Educational Research Association, Washington, DC.

Goodson, I. F. (1992). (Ed.). Studying teachers' lives. London: Routledge.

Goodson, I. F., \& Cole, A. L. (in press). Teachers'professional knowledge: Constructing identity and community. Teacher Education Quarterly.

Goodson, I. F., \& Walker, R. (1991). Biography identity and schooling. London: Falmer Press.

Guyton, E., \& McIntyre, D. J. (1990). Student teaching and school experiences. In W. R. Houston (Ed.), IIandbook of research on teacher education (pp. 514-534). New York: Macmillan.

Hollingsworth, S. (1989). Prior beliefs and cognitive change in learning to teach. American Educational Research Journal, 26, 160-189.

Johnson, S. M. (1990). Teachers at work: Achieving success in our schools. New York: Basic Books.

Kagan, D. M. (1992). Professional growth among preservice and beginning teachers. Review of Educational Research, 62, $129-169$.

Kidder, T. (1989). Among schoolchildren. Boston, MA: Houghton Mifflin.

Knowles, J. G. (1988a, April). For whom the bell tolls: The failure of a student teacher and insights into self, teaching, and teacher education. Paper presented at the annual meeting of the American Educational Research Association, New Orleans, LA

Knowles, J. G. (1988b). A beginning teacher's experience: Reflections on becoming a teacher. Language Arts, 65, 702-711.

Knowles, J. G. (1992). Models for understanding preservice and beginning teachers' biographies: Illustrations from case studies. In I. F. Goodson (Ed.), Studying teachers' lives (pp. 99-152). London: Routledge.

Knowles, J. G. (in press). Metaphors as windows on a personal history: A beginning teacher's experience. Teacher Education Quarterly.

Knowles, J. G., \& Cole, A. L. with Presswood, C. (in press). Through preservice teachers' eyes: Exploring field experiences through narrative and inquiry. New York: Macmillan.

Knowles, J. G., \& Hoefler, V. B. (1989). The student teacher who wouldn't go away: Learning from failure. The Journal of Experiential Education, 12(2), 14-21.

Knowles, J. G., \& Holt-Reynolds, D. (1991). Shaping pedagogies against personal histories in preservice teacher education. Teachers College Record, 93, 87-113.

Knowles, J. G. \& Skrobola, N. (1992, April). We watched them "fail": University supervisors' perceptions of preservice teachers who "failed" student teaching. Paper presented at the annual meeting of the American Educational Research Association, San Francisco, CA.

Knowles, J. G., \& Sudzina, M. R. (1991, February) "Failure" in student/practice teaching: A skeleton in the teacher education closet? Paper presented at the annual meeting of the Association of Teacher Educators, New Orleans, LA.
Laboskey, V. K. (1991, April). Case studies of two teachers in a reflective teacher education program: "How do you know?" Paper presented at the annual meeting of the American Educational Research Association, Chicago, IL.

Lanier, J. E., \& Little, J. W. (1986). Research on teacher education. In M. C. Wittrock (Ed.), Handbook of research on teaching (3rd ed., pp. 527-569). New York: Macmillan.

Lasley, T. J., \& Watras, J. (1991). Teacher education at the crossroads. In L. G. Katz \& J. D. Rath (Eds.), Advances in teacher education (pp. 1-19). Norwood, NJ: Ablex.

Lortie, D. (1975). Schoolteacher. Chicago: University of Chicago Press.

McLaren, P. (1986). Schooling as a ritual performance: Towards a political economy of educational symbols and gestures. London: Routledge and Kegan Paul.

Mcneely, S. R., \& Mertz, N. T. (1990, April). Cognitive constructs of preservice teachers: Research on how student teachers think about teaching. Paper presented at the annual meeting of the American Educational Research Association, Boston MA.

Pape, S., \& Dickens, J. (1990, February). Learning the wisdom to teach. Paper presented at the annual meeting of the Association of Teacher Educators, Las Vegas, NV.

Riner, P., \& Jones, W. P. (1990, February). The reality of failure: Two case studies in teaching. Paper presented at the annual meeting of the Association of Teacher Educators, Las Vegas, NV.

Ross, E. W. (1987). Teacher perspective development: A study of preservice social studies teachers. Theory and Research in Social Education, 15, 225-243.

Schwab, R. (1989, March). Stress and the intern teacher: An exploratory study. Paper presented at the annual meeting of the American Educational Research Association, San Francisco, CA.

Shack, S. (1965). Armed with a primer: A Canadian teacher looks at children. schools. and parents. Toronto, Ontario: McClelland \& Stewart.

Watts, D. (1987). Student teaching. In M. Haberman \& J. M. Backus (Eds.), Advances in teacher education (Vol. 3, pp. 151-167). Norwood, NJ: Ablex.

Weinstein, C. S. (1988). Preservice teachers' expectations about the first year of teaching. Teaching and Teacher Education, 4, 31-40.

Weinstein, C. (1989). Teacher education students' preconceptions of teaching. Journal of Teacher Education, 40(2), 53-60.

Wright, B. D., \& Tuska, S. A. (1968). From dream to life in the psychology of becoming a teacher. School Review, 36, 115-132.

Zeichner, K. M. (1992). Rethinking the practicum in the professional development school partnership. Journal of Teacher Education, 43(4), 296-307.

Zeichner, K. M., \& Gore, J. M. (1990). Teacher socialization. In W. R. Houston (Ed.), Handbook of research on teacher education (pp. 329-348). New York: Macmillan.

Zeichner, K. M., \& Grant, C. A. (1981). Biography and social structure in the socialization of student teachers: $A$ reexamination of the pupil control ideologies of student teachers. Journal of Education for Teaching, 7, 298-314.

Zeichner, K. M., \& Liston, D. P. (1987). Teaching student teachers to reflect. Harvard Educational Review, 57, 23 48.

Zitlow, C. S. (1986). A search for images: Inquiry with preservice teachers. ERIC 284211. 